UDK 504.062; 330.15

\title{
The concepts of resource efficiency and corporate environmental responsibility: a brief overview of the ERREC intensive week in St. Petersburg
}

\author{
Ph.D. Sergienko O.I. oisergienko@ corp.ifmo.ru \\ Dinkelaker N.V. nvdinkelaker@corp.ifmo.ru \\ ITMO University \\ 191002, Russia, St. Petersburg, Lomonosov str., 9 \\ Ph.D. Arrevaara E. eeva. aarrevaara@lamk.fi \\ Kärnä P.paivi.karna@lamk.fi \\ Lahti University of Applied Sciences \\ Niemenkatu 73, 15140, Lahti, Finland
}

Ph.D. Sammalisto K. kaisu.sammalisto@hig.se

Jonsson D. daniel.jonsson@hig.se

University of Gävle

80176, Gävle, Sweden

\author{
Ph.D. Sorvary J. jaana.sorvari@aalto.fi \\ Ph.D. Serkkola A. ari.serkkola@ aalto.fi \\ Aalto University \\ P.O. Box 15200, 00076 Aalto, Finland
}

Over 40 participants from five universities and four companies attended and actively contributed to the Intensive week "Sustainable Product Design \& Resource Efficiency" organized at the ITMO University in St. Petersburg, 10-14 October, 2016 as a part of the ERREC «Environmental Responsibility and Resource Efficiency in companies» project, funded by the Nordic-Russian Cooperation in Education and Research program (SIU) and the Nordic Council of Ministers. Representatives of universities, including students, and business exchanged their views on how resourceefficiency could be achieved and the environmental impact of current consumption and production patterns decreased. $A$ number of key tools and recommendations were formulated for companies under the new educational paradigm of blended learning, which is introducing a mix of traditional and modern educational methods. The trainees obtained a comprehensive experience for solving specific industry-related problems from the viewpoint of resource efficiency on the basis of pre-course assignments, lectures, teamwork, round-table discussions and an excursion. Particularly the waste management problems in Russia and abroad were highlighted. This paper summarizes the lectures and results from the case studies focusing on technical, managerial, and new information and communication technology applications for improving resource efficiency, and developing environmental responsibility in companies.

Keywords: resource- efficiency, sustainability, environmental responsibility, industry, legislation, best available technology, waste management, blended learning.

DOI:10.17586/2310-1172-2016-9-4-95-101

\section{Концепции ресурсной эффективности и корпоративной экологической ответственности: краткий обзор интенсивной недели по проекту ERREC в Санкт-Петербурге}

Канд. техн. наук Сергиенко О.И. oisergienko@ corp.ifmo.ru

Динкелакер Н.В. nvdinkelaker@ corp.ifmo.ru

Университет ИТМО

191002, Россия, Санкт-Петербург, ул. Ломоносова, 9

Канд. техн. наук Арривара Ева eeva. aarrevaara@lamk.fi

Карна Пяйве paivi.karna@lamk.fi

Университет прикладных наук Лахти

15140, Лахти, Нимиенкату 73, Финляндия 


\author{
Канд. техн. наук Сумалисто Кайсу kaisu.sammalisto@ hig.se \\ Джонссон Даниэль daniel.jonsson@hig.se \\ Университет Евле, \\ 80176, Евле, Швеичи \\ Канд. техн. наук Сорвари Яаана jaana.sorvari@aalto.fi \\ Канд. техн. наук Серркола Ари ari.serkkola@aalto.fi \\ Университет Аалто \\ 00076, Аалто, Финляндия, Р.О. Вох 15200
}

\begin{abstract}
Более 40 участников из пяти университетов и четырех компаний приняли участие в интенсивной неделе "Устойчивый дизайн продукции и ресурсная эффективность», организованной Университетом ИТМО в Санкт-Петербурге 10-14 октября 2016 года в рамках проекта ERREC «Экологическая ответственность и ресурсная эффективность компаний», финансируемого программой "Сотрудничество России и Северных стран в образовании и научных исследованиях» Совета министров Северных стран. Представители бизнеса и университетов, в том числе и студенты, обменялись мнениями о том, как может быть достигнута ресурсная эффективность и как $с$ помощью существующих моделей потребления и производства может быть снижено негативное воздействие на окружающую среду. Был сформулирован ряд ключевых инструментов и рекомендаций для компаний в рамках новой образовательной парадигмы смешанного обучения, которая сочетает традиционные и современные методы обучения. Обсуждался опыт решения конкретных отраслевых проблем, связанных с эффективностью использования ресурсов на основе выполнения предварительных заданий, лекций, работы в команде, обсуждений на круглых столах и экскурсий на предприятия. В частности, были освещены проблемы управления отходами в России и за рубежом. В настоящей статье кратко рассматриваются содержание лекций и исследовательских кейсов, посвященных новым техническим, управленческим, информационным и коммуникационным технологиям, применяемых для повыщения эффективности использования ресурсов и развития экологической ответственности компаний.
\end{abstract}

Ключевые слова: ресурсная эффективность, устойчивость, экологическая ответственность, промышленность, законодательство, наилучшие доступные технологии, управление отходами, смешанное обучение.

\title{
Introduction
}

On 10-14 October 2016, the ERREC «Environmental Responsibility and Resource Efficiency in Companies» project successfully organized an intensive week under the theme «Sustainable Product Design \& Resource Efficiency» at ITMO University, St. Petersburg. With the support of the Nordic-Russian Cooperation in Education and Research program (SIU) and the Nordic Council of Ministers over 40 foreign and Russian students, teachers and researchers from five universities took part in the event. The universities were Lahti University of Applied Sciences (Finland), Aalto University (Finland), University of Gävle (Sweden), St. Petersburg National Research University of Information Technologies, Mechanics and Optics (ITMO) and Yaroslav-the-Wise Novgorod State University (NovSU).

The main idea behind ERREC (2016) project is to bring higher education institutions (HEIs) in Russia, Finland and Sweden into closer cooperation with each other and to plan how to do this by involving also companies. The activities in the project include two events with students and companies, an intensive week, meetings, visiting lectures for sharing information and dissemination and publications. The work is aiming at a long-term collaboration between the ERREC partners in the future.

The intensive week consisted of lectures given by all ERREC partners representatives, group works, an international seminar with some companies involved, an excursion to a company and a one-day visit to NOvSU University in Velikyi Novgorod. The participating companies were JSC «Baltika Breweries», JSC «Coca Cola», JSC «Nordena» and JSC «Ptitsefabrika-Severnaya». Before taking part in the week, the participating students were given a preliminary assignment related to food industry and transportation services.

The lectures and the international seminar focused on improving resource efficiency and modernization by implementing best available techniques (BATs) and best practices of corporate environmental management based on the foreign and Russian experiences. Case studies presented in the lectures also brought up some developments in managerial processes and information and communication technology (ICT) for improving resource-efficiency.

Resource and energy efficient production in industries, the brewery industry in Sweden and Russian enterprises operating in beverage production were of particular interest to the participants. Specific waste management problems in Russia and abroad were discussed. Many of the presentations focused on problems in waste management, which are extremely current in Russia. One topic of interest was the classification of wastes based on toxicity and industrial symbiosis as a practical means to attain resource efficiency. In 2017, the existing system of payment for negative 
environmental impact in Russia will be supplemented by new environmental fees aiming at stimulating recycling of production and consumption waste, which highlighted the urgency of the latter topic.

\section{Blended learning: a method for adopting ideas on improved resource-efficiency and corporate environmental responsibility}

Blended learning is a new kind of pedagogical approach, which has become more wide-spread in higher education during recent decades. The concept was originally used to describe learning in industry and at workplace. By the adaptation of blended learning, teachers can use the elements of both face-to-face meetings and distant learning to provide more balanced educational solutions. The traditional contact teaching can be described as a synchronous learning method taking place in a classroom. Online solutions allow the use of asynchronous methods where students are able to work with the learning tasks in their own time. There is a variety of tools available for distance learning and part of them are also used in a synchronous way. However, the increase of online and distant learning has also brought negative impacts from the viewpoint of different types of learners, though [1].

While campus based learning has been understood as delivery of content, new needs for student support are needed. In the same time new patterns for content delivery have become available and the synchronous meetings can be used for common working and discussion or other face-to-face activities. In ERREC project different synchronous and asynchronous methods were adapted in student work.

Also industrial companies need to be aware of the urgently needed renouncement from the unsustainable operation that has caused many of the present global problems: In addition, companies need information on how they can become more energy and resource efficient in order to contribute to such a change. Although the reasons for climate change are debated in media, research confirms the fact that human activities severely contribute to it. Therefore, all human activities should take place within the resilience limits of the planet [2].

Business opportunities in increasing energy and resource efficiency can enable companies' long life time and increased profit of if they are willing to take the challenge in making the required changes. Maximizing profit in short term is attractive, but for the long term survival companies need to be aware that in the future, any changes in the operational environment, e.g. new legislation and other requirements from the society, are likely to force them to adjust. International corporations acknowledge this and publish their sustainability reports (GRI). Moreover, they are increasingly extending their requirements to their suppliers.

\section{Methods of blended learning in ERREC and during the intensive week}

Different synchronous and asynchronous methods were adopted in student tasks in belonging to ERREC and also during the intensive week. Prior to the intensive week, the participating students were asked to work with a pre assignment, whose results were then presented in the beginning of the week. The programme of the week contained synchronous lectures and group work with the representatives of local enterprises and tutors, as well as an excursion to one participating company. After the face-to-face contact period the students continued group work by using online methods.

Before taking part in the week, the students were given a pre-assignment related to food industry and transportation services. Each student team chose a branch of industry out of list of industries for their assignment and made a presentation about their findings. The pre-assignment addressed the following questions:

- What kind of good practices/best available technology is used in the company/branch in your own country to take the environmental responsibility and to promote resource efficiency?

- What are the key determinants of resource-efficiency in the particular type of industry?

- What kinds of innovations (environmental, social and other) are needed in the company to improve their present activities, to take their environmental responsibility and to promote resource efficiency?

Resource and energy efficient production in the companies, the brewery industry in Sweden and Russian enterprises producing beverages were of particular interest to the participants.

The second part of the group work during the intensive week launched at the round table discussions as a part of the international conference. The round table discussions focused on finding ideas on how to enhance the material and energy efficiency of the participating companies. The questions and topics discussed were:

1. How would you improve resource efficiency in Production?

2. How would you improve resource efficiency in Consumption?

3. How would you improve resource efficiency in Product?

4. How would you improve resource efficiency in Raw material acquisition?

5. Give proposals of wider sustainability aspects.

After discussing different ideas with companies involved in the groups, the students carried on with the group work among themselves in two meetings during the intensive week, and later on distantly using email and other means of e-communication. The groups delivered their final reports one week after the intensive week. 
To support blended learning in the future, the visiting lectures held during the project were recorded for later use. The recording was carried out using a web conference program (Adobe Connect), which enables the use of the recordings as a part of teaching in other occasions. Some of the recorded lectures will be published on ERREC's web page at www.lamk.fi/errec.

\section{Overview of the results from the intensive week}

The lectures during the week handled the following themes: sustainability as a wide concept, business models in Russia, waste management and classification of wastes, drivers and barriers of reuse/recycling/refurbishing of wastes, digitalization of the waste management chain, and sustainability in buildings.

In her presentation Kaisu Sammalisto, Associate Professor at the University of Gävle, initiated a discussion about the meaning of the word «sustainability». According to Prof. Sammalisto, weak sustainability means looking and operationalising different sustainability aspects (ecological, social and economic) separately, while strong sustainability can only be reached through understanding that all human activities need to take place within the limits of the whole ecological system, the earth. Different kinds of collaboration activities, for example between universities, companies and non-governmental organisations (NGOs) are needed to attain a sustainable future. Here the students have an important role through participating in projects and preparing their theses in companies within their speciality under the supervision of the university faculty.

The lecture of Dr. Olga Sergienko, Associate Prof. and Head of Industrial Ecology Department, ITMO University focused on sustainable business models for raising resource- and energy efficiency. A business model is a connectional tool to help understand how a firm does business and it can be used for analysis, comparison and performance assessment, management, communication and innovation [3]. The recent typology gives opportunity to differentiate between the three existing business models (technological, social and organizational), and show how they can generate the environmental and/or social benefits in business operations [4]. Investigation of the intersections of various business models represents an important topic for the researches in the field of corporate social and environmental responsibility.

Sustainable business models are oriented towards eco-innovations, eco-efficiency raising and socially responsible practices, which are currently in the focus in industry's sustainable development agenda worldwide. This can be seen in the growing number of publications in the prestigious scientific journals devoted to the analyses of the various business models and their mutual integration [5-8]. Moreover, open access corporate reporting has become increasingly frequent [9]. A similar trend is also noticeable in the Russian industry especially in large corporations. The importance of the implementation of new business models in Russian companies can be supported by the new edition of the ISO 14001 international standard [10] as well as the ongoing reform of the environmental regulation based on establishing the specific technological norms of environmental impact and their transition to the best available techniques [11, 12].

One of the key issues of designing business models is how to find a way that enables a company to create profit (economic value) for itself by simultaneously delivering with social and environmental benefits. It is already clear that eco-efficiency, rational use of resources and quality improvements may be readily translated into profits. It is not always so clear how delivering social and environmental value might translate into profit and competitive advantage. A literature review shows that corporate innovations in the social and environmental field may be used to enhance sustainable innovations. The social and environmental innovations have been in the focus of research agenda during the last decade. The business development is changing from product and services to new business models, thereby changing the way of doing business.

The new business models can be implemented alone and be also integrated in companies and thus creating many innovation managerial approaches. For example, increase of material and energy efficiency can be attained through dematerialization and leasing, renting, sharing, i.e. by means of delivering functionality instead of ownership. However, due to the current legislative reforms and transfer to BATs, the Russian companies most likely need business models of technological type. When implementing a new business models it is useful to take into account indicators of resourceefficiency and environmental impacts as well as the life cycle costs. As such the indicators can serve as the metrics of the global environmental impact by categories both at the inputs and outputs of the production chains.

Natalia Dinkelaker, the Head of the Eco-monitoring laboratory of the ITMO University brought forward another important change in the Russian environmental legislation. Her presentation dealt with the Russian regulations concerning waste classification methods. Establishment of an order of confirmation of reference of waste of the I-V classes of danger is currently based on calculation and experimental methods based on bioassays [13]. The experimental method is used when the content of waste is unknown. Advantages of the experimental method, such as the possibility of counting for mixture effects of multiple contaminants on living organisms and high sensitivity of test organisms enable a reliable assessment of a waste's impact on an ecosystem. The disadvantages are related to the vast choice of methods and test organisms and the difficulties of choosing the most bioassays in a particular case. In addition, the interpretation of results is often challenging particularly due to natural variability of the organisms. Determination of the reactions of waste toxicity in the changing environment conditions opens the new research opportunities. 
Waste management was also the topic in the presentations of the representatives of Aalto University, Finland. First Dr. Jaana Sorvari, Associate Professor in the School of Engineering, Department of Built Environment discussed the principles of defining residues as wastes or alternatively, as (by-)products in the EU and the implications of such classifications for their reuse and recycling. Even if the definition per se sounds simple it is actually not unambiguous. In fact, the discussion on what is waste and what is not waste has been ongoing for years already. The liability of the possessor of a residue depends on this classification. In case of a waste, the one who currently holds the waste is responsible for any adverse environmental impacts (including human health) it may cause. Whereas in the case of a (by-) product, the liability remains with the producer. This difference is crucial from the viewpoint of somebody who considers using a residue instead of virgin material or a manufactured product.

In 2008, the European Commission issued a Waste Framework Directive (WFD) that includes End of Waste (EoW) criteria, i.e. generic prerequisites per which a waste ceases to be waste. These criteria can be used to define wastespecific EoW criteria at the European or national level. By December 2016, such EU level criteria are available only for five materials, i.e. for certain metal scraps and glass cullet. The regional authorities can also apply the generic EoW criteria and by their decision state that a specific waste generated in their region is not waste. In Finland, only a couple of such decisions have been documented so far.

Creation of industrial symbiosis is an alternative and probably much simpler and clearly a more frequent means to recycle residues. In the recycling of residues, industrial symbiosis means that one actor's residue is another actor's resource, e.g. a raw material in a process. Industrial symbiosis is a local/regional-level solution to recycling of wastes. Several symbioses exist already around the world and also in Finland - information on the current Finnish symbiosis can be found at industrialsymbiosis.fi. A reliable quality control is a prerequisite for a functioning industrial symbiosis system as well as for any other system of recycling or reusing wastes. At least in Finland the strict environmental criteria that are based on a conservative precautionary principle seem to be a true barrier to recycling. The Finnish government has finally acknowledged this barrier and alleviation of administrative permitting procedures is ongoing. Overall, recycling of wastes requires balancing between different objectives, i.e. attainment of circular economy, resource-efficiency, sustainability etc. against environmental requirements.

Ari Serkkola, Docent, Leading Research Scientist in the Department of Built Environment at Aalto University's School of Engineering told about Waste order and monitoring service for supply chains. Expectations towards the monitoring and reporting of municipal solid waste and material flows are increasing, e.g. owing to the EU's WFD [14]. Serkkola's presentation focused on demonstration of municipal solid waste (MSW) monitoring system.

The demonstration was based on the national research programme on material value chains (known as ARVI) implemented in Finland between 2014 and 2016. In the demonstration, data on generation of MSW is collected when emptying waste containers in the property collection system (Figure 1). The waste container is first identified by Radio Frequency IDentification (RFID) tag and then weighed by the scale of the collection vehicle in pursuance of emptying (number 1). The data is saved to the computer in the vehicle (number 2) and transferred to a server (number 3 ).

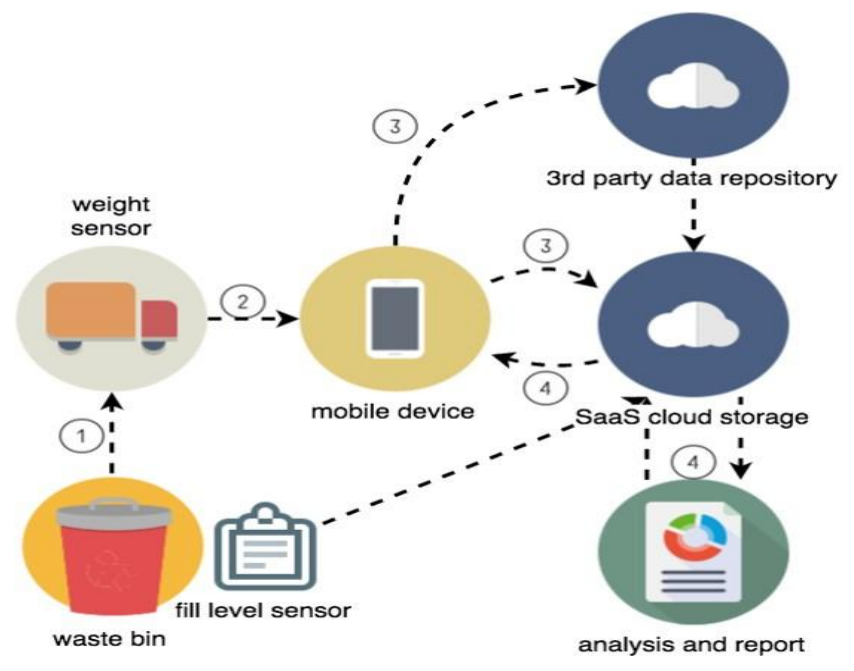

Figure 1. Weigh-in data collection in real time monitoring

1 - Bin or container has an identification ID code (RFID Radio Frequency IDentification);

2 - Reader identity ID and data is transferred to TCS Transport Control System in truck;

3 - Data transfer wireless to waste management server (IT company);

4 - Weight and other reference data is analyzed and reported in real time to producers and waste management companies 
The data includes the type and the amount of waste, the location of the container, and the emptying date and time. The monitoring services are supported by indicators, which describe the changes and development trends in the amount of wastes, logistics, costs, and environmental impacts. These indicators provide information for decision making. Figure 2 illustrates a pilot carried out in Helsinki, Laajasalo housing area. The Figure 2 illustrates the combining of weight data $(\mathrm{kg})$ in monitored containers with the socioeconomic grid database [15].

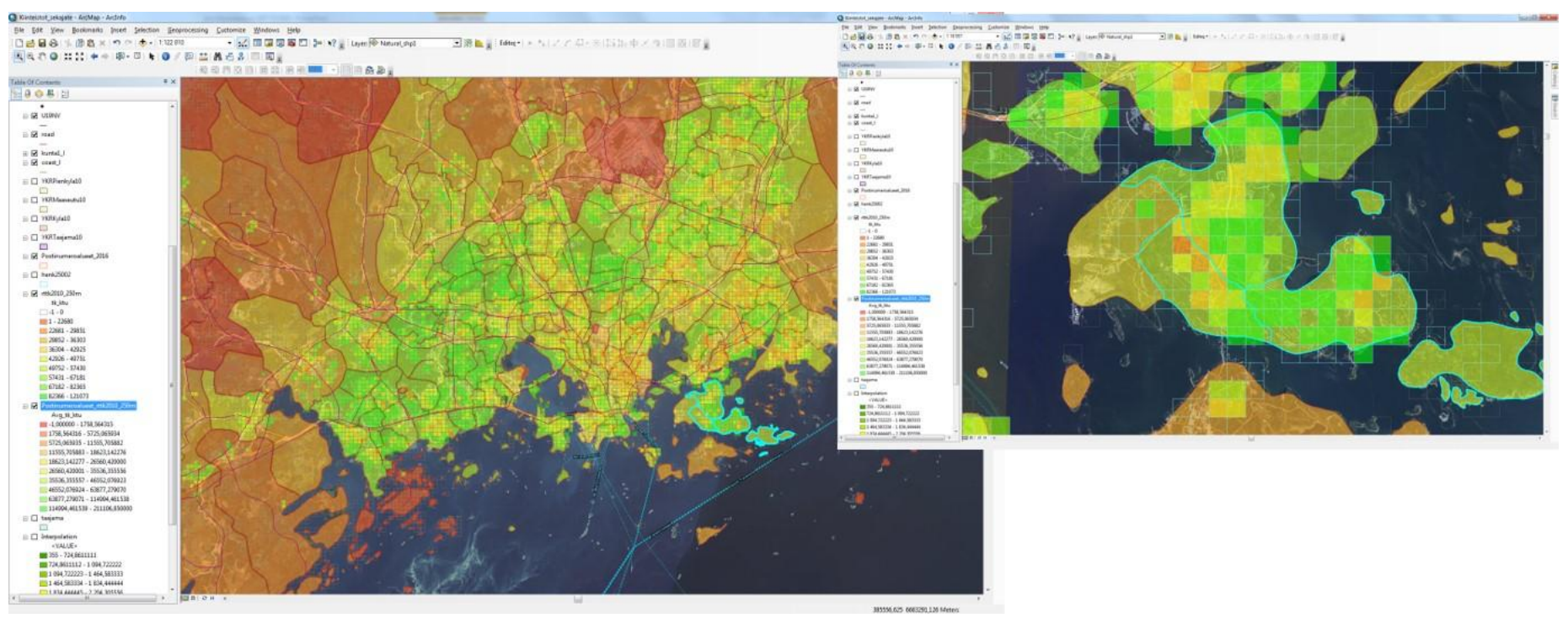

Figure 2. Pilot in Helsinki Laajasalo: mixed waste collection, weight data (kg) in monitored containers combined with the socioeconomic grid database (Statistics Finland)

Different stakeholders in waste management - residents and workers, properties and waste management companies - can use the same data as per their own monitoring needs. Property owners can utilize the monitoring services for improving their sorting and recycling activities, but also for optimizing container size and the schedule for emptying the containers, among others. Waste transportation companies can use the data for planning the pick-ups and transport routes, producing maps to give a clear navigation view for drivers, and forecasting the amount of waste and loads during specific seasons. Municipal decision-makers can evaluate the functioning of waste management based on identified housing companies, housing areaes and regions where waste amounts are different compared with other equivalent areas.

They can also identify whether e.g. building type, socioeconomic status or waste management services cause differences in the amount of waste produced.

Sustainable product design in construction was discussed by Dr. Eeva Aarrevaara, Principal lecturer in Lahti University of Applied Sciences, Faculty of Technology. Her presentation introduced some negative impacts of unsuccessful material solutions in construction. Traditional building materials has been replaced by a variety of products which don't always fit together and cause for example air quality problems in modern buildings. The so called "sick building syndrome" has been discovered to cause multiple health symptoms to persons who are sensitive to the inside conditions.

It is essential to perceive the environmental impact during the whole life-cycle of buildings. Planning of a building is a very crucial phase because several major choices concerning building - like main constructions and material - are made during it. Thus, the whole lifecycle of buildings should be always considered in the planning phase, including the opportunities to recycle and reuse building parts and materials. Construction phase causes also impacts to the surroundings of the building area. Use phase covers the maintenance of buildings and user experiences which are individual. The last phase, demolition, involves processes of reuse of building waste. The user of waste should be involved already in the planning phase to properly understand the functions and needs of space.

Planning of a building is a very crucial phase because several major choices concerning building - like main constructions and material - are made during it. Thus, the whole lifecycle of buildings should be always considered in the planning phase, including the opportunities to recycle and reuse building parts and materials. Construction phase causes also impacts to the surroundings of the building area. Use phase covers the maintenance of buildings and user experiences which are individual. The last phase, demolition, involves processes of reuse of building waste. The user of waste should be involved already in the planning phase to properly understand the functions and needs of space.

Green Building Council Finland (2016) has gathered information about different tools and measurements to evaluate sustainability of buildings in different ways [16]. They are connected to the building's life cycle, energy efficiency, carbon emissions, indoor air quality and user satisfaction. A comparison of the main contents of two different sustainability certificate systems was included in the lecture: BREEAM (Building Research Establishment's Environmental Assessment Method) and LEED (Leadership in Energy and Environmental Design). 
It was concluded that there are lots of different tools to help the designers and planners to evaluate the environmental and energy impacts of constructions, even including air quality and individual user satisfaction. Although, the tools don't replace experience, knowledge and skills in sustainable construction design but they are able to help the process. The whole lifecycle of buildings should be always considered in the planning phase, including the opportunities to recycle and reuse building parts and materials. The project finding needs lots of development in the future.

\section{Conclusions}

As more natural resources are being consumed and more pollution is generated by current consumption and production patterns, it is becoming increasingly clear that in order to decouple economic growth from adverse environmental impacts arising particularly from the emissions of toxic substances and greenhouse gases, the companies and industries must become more resource-efficient. The central topic of resource efficiency is that it requires improvements of corporate environmental strategies and policies in all dimensions of the company's life, providing sustainable consumption and production of goods and services. Key tools and strategies include sustainable product design, extended producer responsibility, waste recycling, transition to best available techniques, environmental monitoring services for supply chains and adequate economic, legislative and informational policy instruments.

New business models and circular economy approaches need to be developed and implemented despite of any barriers, cultural aspects and habits. Accessibility of data for decision-making in companies is a critical factor for resource-efficient industrial development. Improvements on the production side must be accompanied by the demand side reductions. To stop the growing resource consumption, a change of current unsustainable behavior and personal values is necessary. During the ERREC project it also came up that there is a need for exchanging information between the Nordic countries and Russia since the environmental legislation and central concepts differ from each other by definition and contents. Understanding and recognizing the differences in the operational environment, such as the regulatory framework, are essential for the exchange of technological knowhow and good practices between the countries.

\section{Bibliography}

1. Macdonald, J. Blended learning and online tutoring. Planning learner support and activity design, England, 2008.

2. Rockström et al. (2009). Planetary boundaries: exploring the safe operating space for humanity. Ecology and Society 14(2) 32. URL:http://www.ecologyandsociety.org/vol14/iss2/art32/ (accessed 28.11.2016).

3. Baumann H., Boons F. and Bragd A. Mapping the green product development field: engineering, policy and business perspectives/ Journal of Cleaner Production, Vol. 10, No. 5, 2002. pp. 409-425.

4. Bocken N.M.P., et al. A literature and practice review to develop sustainable business model archetypes/ Journal of Cleaner Production, Vol. 65, 2014. pp. 42-56.

5. Feld, W.M. Lean Manufacturing - Tools, Techniques, and How To Use Them / The CRS Press Series on Resource Management, USA, 2001.

6. Glenn Johansson1, Mats Winroth. Lean vs. Green manufacturing: Similarities and differences / Conference: 16th International Annual EurOMA Conference: Implementation - realizing Operations Management Knowledge, At Göteborg, Sweden, 2009.

7. Lewidow L., et al. Process eco-innovation: assessing meso-level eco-efficiency in industrial water-service system/ Journal of Cleaner Production, Vol. 110, 2016 pp. 54-65.

8. Rohn H., Liedtke C., Wiezen K. Measuring side effects of a closed carbon cycle - a case study of a biogas plant in Germany, Energies, Vol. 7, No. 6, pp. 1-14, 2014.

9. UPM Sustainability Report 2014.

10. ISO 14001:2015 Environmental Management Systems. Requirements.

11. Energy Strategy of Russia for the period up to 2030. Russian Federation Government Order from 13.11.2009 № 1715-p. [Electronic resource] // http://www.energystrategy.ru/ Site Institute of Energy Strategy. Date: 2009 (accessed 28.11.2016).

12. Federal Law dated of 21.07.2014 N 219-FZ «About amendments to the Federal Law «On Environmental Protection and other legislative acts of the Russian Federation».

13. The order of the Ministry of natural resources and ecology of Russia from 12.04.2014 N 536 «About the statement of Criteria of reference of waste to the I-V classes of danger on degree of negative impact on the environment».

14. Directive 2008/98/EC of the European Parliament and of the Council of 19 November 2008 on waste and repealing certain Directives. Official Journal of the European Union 312/3. 28.11.2008.

15. Statistics Finland. http://www.stat.fi/index_en.html/ (accessed 28.11.2016).

16. Green Building Council Finland. 2016. http://figbc.fi/en/gbc-finland/ (accessed 28.11.2016). 